\title{
Review
}

\section{Role of Microglia in Autism: Recent Advances}

\author{
Tomoyuki Takano \\ Department of Pediatrics, Shiga University of Medical Science, Otsu, Japan
}

\section{Key Words}

Autism $\cdot$ Microglia $\cdot$ Autism spectrum disorder

\begin{abstract}
The neurobiological basis for autism remains poorly understood. However, the neuroinflammation processes play an important role in the induction of autistic behavioral changes. Microglial cells can exhibit widely differing functions during brain development, including synaptogenesis and stem cell proliferation, in addition to playing a role in the innate immunity. Mounting evidence indicates that microglial activation or dysfunction can profoundly affect neural development, resulting in neurodevelopmental disorders, including autism. These mechanisms in autism have been investigated using neuropathological studies of human autopsy brains, a large number of murine experimental models and in vivo neuroimaging studies of the human brain. The purpose of this review is to discuss microglial activation or dysfunction and to highlight the detrimental role that microglia play in the development of autism. The recent advances presented in this review support that further elucidation of the mechanisms and kinetics of microglial responses will help to establish a window for therapeutic intervention in individuals with autism.

(c) 2015 S. Karger AG, Basel
\end{abstract}

\section{Introduction}

Autism is a set of heterogeneous neurodevelopmental conditions characterized by early-onset difficulties in social communication and unusually restricted, repetitive behavior and interests. The worldwide population prevalence is approximately $1 \%$, and $2-3$ times more males are affected than females. Genetics play a key role in the etiology of autism, in conjunction with developmentally early environmental factors [1]. The neurobiological basis for autism remains poorly understood. However, numerous investigations have suggested that immune abnormalities are one of the most important contributing factors in the development of autism [2,3]. Serum antibodies against central nervous system (CNS) antigens and maternal antibodies to fetal brain proteins have been associated with autism [4-6]. Maternal IgG reactive to fetal brain proteins has been experimentally shown to contribute toward autism development via the induction of behavioral alterations in offspring mice or monkeys. These offspring had been prenatally exposed to serum IgG obtained from the mothers of autistic children $[7,8]$. Therefore, neuroinflammation processes in the brain may play an important role in the induction of autistic behavioral changes $[9,10]$.

\section{KARGER 125}

E-Mail karger@karger.com www.karger.com/dne (c) 2015 S. Karger AG, Basel

0378-5866/15/0373-0195\$39.50/0
Tomoyuki Takano, $\mathrm{MD}, \mathrm{PhD}$

Department of Pediatrics

Shiga University of Medical Science

Seta-Tsukinowa, Otsu 520-2192 (Japan)

E-Mail tmyktkn@belle.shiga-med.ac.jp 
Deficits in synaptic maturation, which are characterized by weak functional connectivity across brain regions, may play a role in the pathophysiology of neurodevelopmental disorders, including autism [11]. Microglia are the representative mononuclear phagocytes in the CNS and ultimately have a myeloid origin [12]. The concept of repopulating brain microglia from bone marrow-derived cells in adult mice under normal physiological conditions is controversial [13]. However, there is a major wave of migration of the primitive myeloid progenitors into the CNS to become resident microglia [14], and these microglial cells are suggested to contribute to brain development, including synaptic maturation. This review critically summarizes the recent advances that support the important role that microglia play in regulating the development of autism.

\section{Functions of Microglia}

Microglia can exhibit widely differing functions at different stages in life, both physiologically and during various pathological situations [15]. The functions of the microglia during CNS development include the following: (1) phagocytic activity during neuronal/synaptic development (probably reflected in the pruning of redundant neurons and connections), (2) neuronal development influenced by the secretion of cytokines, neurotrophins and growth factors, (3) the removal of cell debris facilitating plasticity and synaptogenesis and (4) the regulation of stem cell proliferation [16]. Microglia colonize the neuronal proliferative zones in the developing neocortex and phagocytose neuronal precursor cells during the late stages of cortical neurogenesis [17]. Augmenting the in utero activation of fetal microglia through maternal immune activation decreases the number of neural precursor cells, while the in utero deactivation or elimination of fetal microglia increases them. Conversely, the enhancement of neurogenesis and oligodendrogenesis by activated microglia is demonstrated in the early postnatal subventricular zone [18]. These results suggest that any factors that alter the number or activation state of microglia either in utero or during the early postnatal period can profoundly affect neural development, thus resulting in neurodevelopmental disorders, including autism.

Similar to macrophages, microglia adopt different activation phenotypes in response to CNS insults. The activation of microglia results in a range of responses that include morphological alterations, migration to the site of injury and proliferation (microgliosis), as well as an increased expression of several factors, including im- mune mediators. Moreover, microglial cells may transform into highly phagocytic cells, thereby removing dead cells, accumulated debris, protein aggregates, and bacterial and viral pathogens [19]. The definitions of such types of microglial activation are initially based on the peripheral monocytes/macrophages characterized in in vitro experiments and are not entirely identical to those for macrophages. However, two activation phenotypes have been investigated: the classical proinflammatory and neurotoxic phenotype M1 and the alternate anti-inflammatory phenotype M2 [20] (fig. 1).

Exposure of microglial cell cultures to stimuli such as bacterial lipopolysaccharides (LPS) [21, 22], TNF- $\alpha$ [23], IFN- $\gamma$ [24], necrotic neurons [25], oligomers of $A \beta$ [26], and $\alpha$-synuclein $[27,28]$ induce the M1 phenotype. The classical M1 phenotype is characterized by the activation of mitogen-activated protein kinase (ERK1/2 and p38) [22], the expression of MHC-II (major histocompatibility complex type II) cell surface glycoprotein, the secretion of proinflammatory cytokines (TNF- $\alpha$, IL-1 $\beta$, IL- 6 and IL12 ), and the production of reactive oxygen species (ROS). In addition, the upregulation of inducible nitric oxide (NO) synthase (iNOS or NOS2), glutaminase and inducible COX-2 (cyclooxygenase-2) leads to an increase of NO, glutamate and prostaglandins, respectively. Most of these factors released by microglia are neurotoxic for neuronal cell cultures [29]. The alternative M2 phenotype is neuroprotective and can be induced in primary microglial cells by the cytokines IL- 4 and IL-13, which are secreted in vivo by Th2 lymphocytes [30]. The M2 phenotype is characterized by the expression of heparin-binding lectin Ym1, cysteine-rich protein FIZZ1 and arginase 1 by activated microglia [30]. In vitro, IL-4 is found to decrease iNOS activity, superoxide and TNF- $\alpha$ production in LPSand TNF- $\alpha$-activated microglia, along with the rescue of neurons from neurotoxicity [31]. IL-4 also increases the phagocytic activity of microglia, namely the uptake of oligomeric $A \beta$ species through the scavenger receptor CD36 [32]. Additionally, in cell cultures, IL-13 and IL-10, which are anti-inflammatory cytokines produced by macrophages, increase the microglial secretion of activin $A$, a neuroprotective TGF- $\beta$ superfamily member that also promotes oligodendrocyte differentiation [33] (fig. 1).

\section{Microglial Activation in Autism}

\section{Microglial Activation in the Human Brain}

Autism involves early brain overgrowth and dysfunction, which is most strongly evident in the prefrontal cor- 
Fig. 1. Microglial activation phenotypes. M1 is the classical proinflammatory/neurotoxic phenotype, and $\mathrm{M} 2$ is the alternate anti-inflammatory/neuroprotective phenotype. $\mathrm{MAPK}=$ Mitogen-activated protein kinase; $\uparrow=$ increase or upregulation; $\downarrow=$ decrease or downregulation.
M1

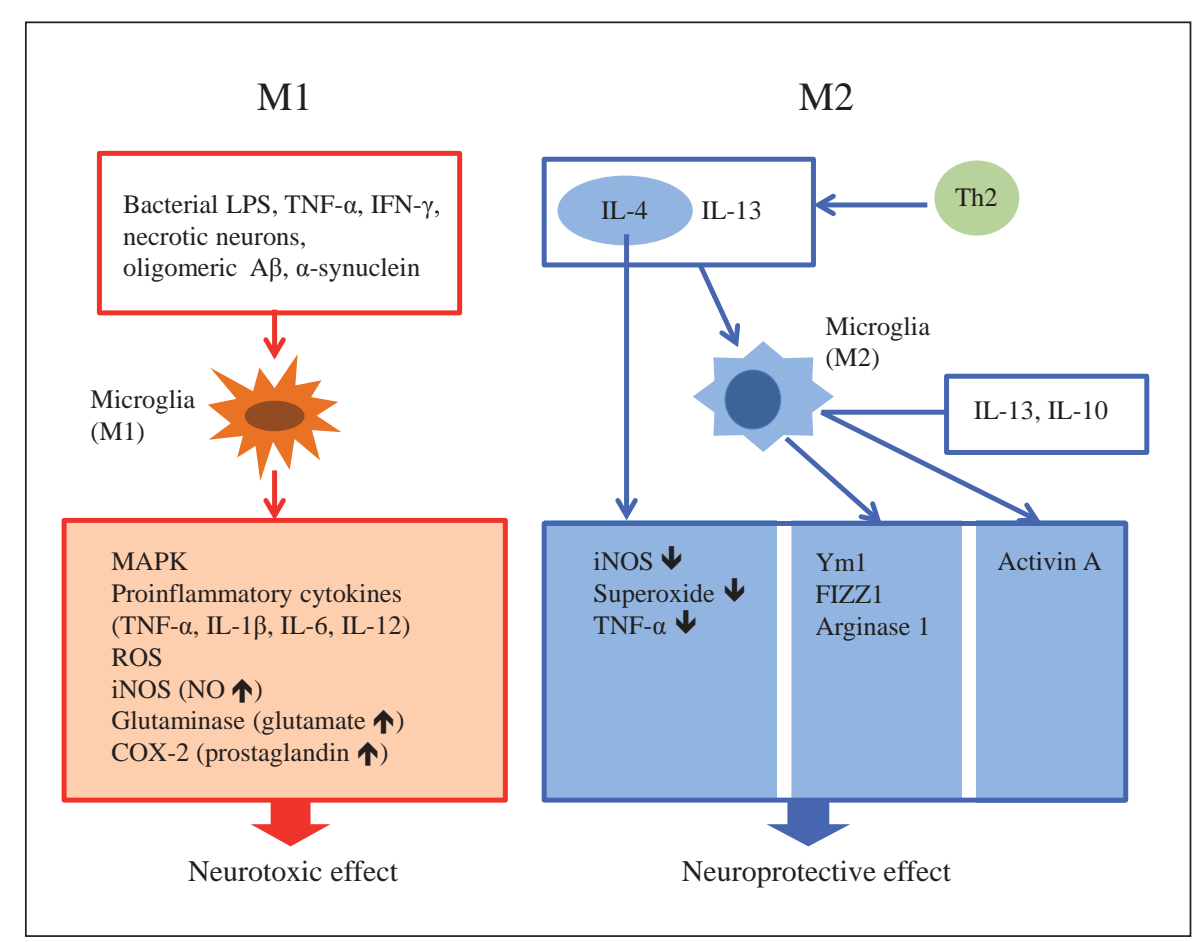

M2

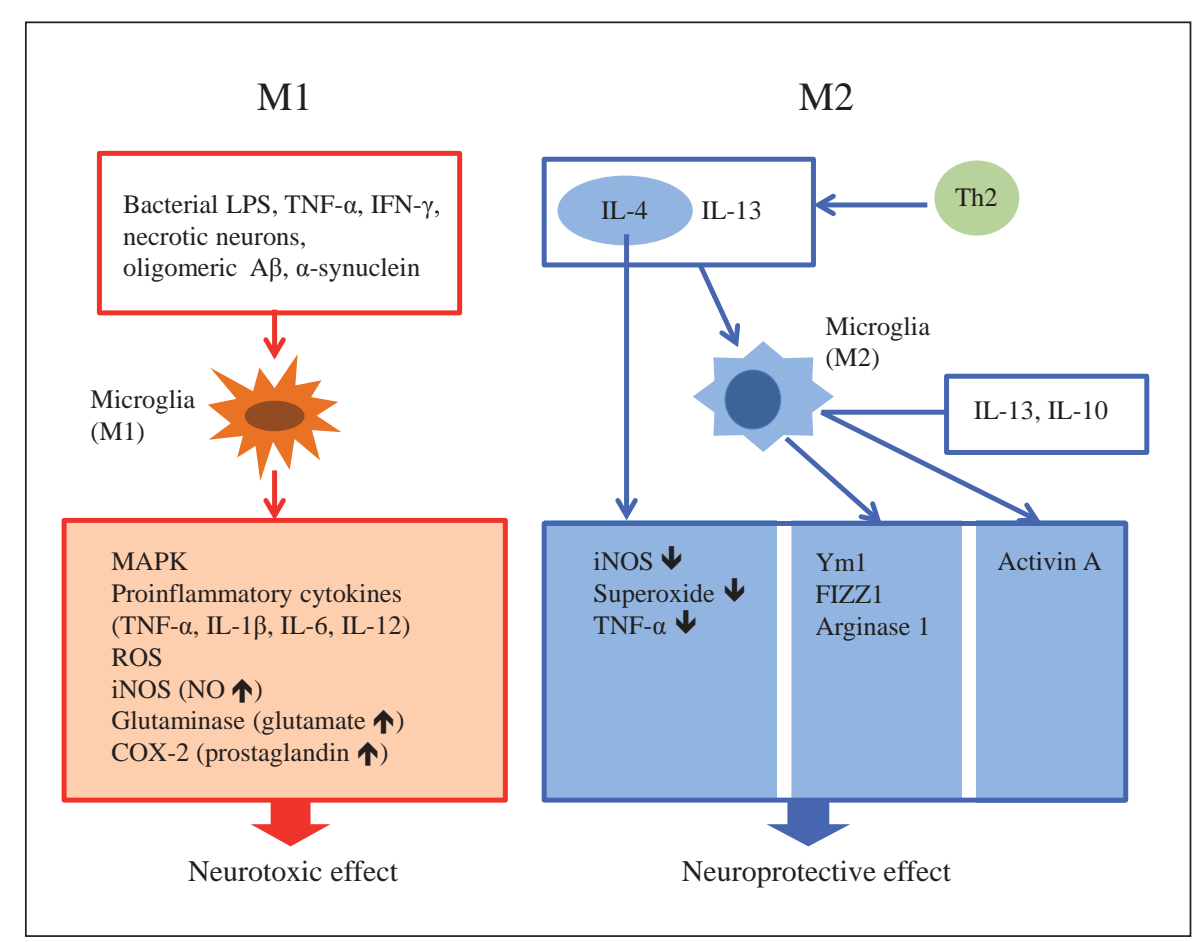

tex. An excess amount of neurons in the prefrontal cortex signals a disturbance in prenatal development and may be associated with an abnormal cell type and laminar development [34]. In postmortem studies of autistic brains, lower numbers of neurons have been reported in the amygdala, the fusiform gyrus of the temporal lobe and the cerebellum [35]. One current line of research emphasizes alterations in the basic columnar organization of the neocortex [36]. Several investigations have indicated microglial activation in human autistic brains. Neuropathological studies of autopsy brains with autism demonstrated the presence of active neuroinflammatory processes in the cerebral cortex, white matter and, most notably, the cerebellum. Immunocytochemical studies have shown a marked activation of microglia and astroglia, and cytokine profiling has indicated that macrophage chemoattractant protein- 1 and tumor growth factor- $\beta 1$, which are derived from neuroglia, were the most prevalent cytokines in the brain tissues [37]. An immunohistochemical study in autopsy brains with autism and matched controls showed significant increased densities of microglia in two functionally and anatomically disparate cortical areas, namely the frontoinsular and visual cortices, suggesting the dense distribution of microglia throughout the cerebral cortex in brains with autism [38]. Microglial and neuronal organization was examined in the dorsolat- eral prefrontal cortex, which is a region of pronounced early brain overgrowth during the development of autism, of 13 male postmortem autism subjects and 9 controls. The autism brains exhibited increased short-distance microglia-neuron interaction, including the encirclement of neurons by microglial processes. In the autism brains, neuron-neuron clustering increased with advancing age. However, microglia-microglia organization was normal at all ages, suggesting that the aberrantly close microglia-neuron association in autism is not a result of altered microglial distribution but a neuron-specific reaction [39]. In some children with autism, the amygdala has an aberrant growth trajectory marked by an early enlargement followed by a normal or even reduced volume by adulthood [40]. In the adult postmortem examination of the amygdala from individuals with autism, there was evident heterogeneity within the autism cohort; however, 2 of the 8 autism brains displayed strong microglial activation [41]. There were fewer oligodendrocytes in the amygdala of older adult individuals with autism, suggesting increasing cognitive difficulties in the later stages of life in autism patients. In addition, a human transcriptome analysis in the control and autistic cortical brains revealed a strong, negative correlation between two differentially co-expressed modules, the activated M2-state microglia genes and the synaptic transmission genes [42]. The M2- 
Table 1. Experimental models of autism due to maternal inflammatory activation involving offspring microglial alteration

\begin{tabular}{llll}
\hline Methods & $\begin{array}{l}\text { Mechanism of } \\
\text { inflammatory activation }\end{array}$ & Pathological findings & Behaviors relevant to autism \\
\hline Poly I:C & $\begin{array}{l}\text { Activation of NF- } \kappa \text { B; } \\
\text { production of TNF- } \alpha, \\
\text { IL-6 and IL-12 }\end{array}$ & $\begin{array}{l}\text { Decreased expression of reelin; } \\
\text { increased expression of GFAP; } \\
\text { increased number of activated microglia }\end{array}$ & $\begin{array}{l}\text { Impairments in nonspatial memory } \\
\text { and learning tasks; motor activity } \\
\text { similar to autistic behaviors }\end{array}$ \\
\hline $\begin{array}{l}\text { Influenza } \\
\text { A virus (H3N2) }\end{array}$ & $\begin{array}{l}\text { Genetic alterations in } \\
\text { maternal Th1 responses }\end{array}$ & $\begin{array}{l}\text { Changes in catecholaminergic neurons; } \\
\text { microglial density in males }\end{array}$ & $\begin{array}{l}\text { Alterations in social and aggressive } \\
\text { behaviors; increased locomotor } \\
\text { behaviors, particularly in males }\end{array}$ \\
\hline LPS & $\begin{array}{l}\text { Enhancement of the } \\
\text { NOX-PI3K pathway }\end{array}$ & $\begin{array}{l}\text { Hyperproliferation of neural stem and } \\
\text { progenitor cells; forebrain microglial } \\
\text { proliferation }\end{array}$ & $\begin{array}{l}\text { Abnormal autism-associated } \\
\text { behaviors }\end{array}$ \\
\hline
\end{tabular}

GFAP = Glial fibrillary acidic protein; Refs. = references.

activation state microglia genes were altered in the autistic brains, potentially driven by type I IFN responses. This process may drive changes in neuronal progenitor cell proliferation and connectivity, with subsequently altered activity-dependent neural expression profiles during postnatal development [42]. These results highlight the interplay between the innate immunity and neuronal activity in the etiology of autism.

In vivo investigations have also been reported. The peripheral benzodiazepine receptor, known as the $18-\mathrm{kDa}$ translocator protein (TSPO), is a cholesterol transporter protein expressed in the membrane of mitochondria of cells throughout the body [43]. A positron emission tomography analysis of TSPO using the radiocarbon $\left[{ }^{11} \mathrm{C}\right]$ (R)-PK11195 enables the visualization of the activated microglia in vivo in the whole brain [44]. This procedure demonstrated the $\left[{ }^{11} \mathrm{C}\right](\mathrm{R})-\mathrm{PK} 11195$ binding potential values to be significantly higher in multiple brain regions in young adults with autism compared to those of controls, suggesting excessive microglial activation in multiple brain regions in autism patients [45]. Historically, the increase in TSPO expression was attributed to the activation of the microglia within the CNS [46]. However, there is now growing evidence that reactive astrocytes also show an increase in TSPO binding after brain insult [47]. A new TSPO ligand, ${ }^{18} \mathrm{~F}-\mathrm{GE}-180$, is able to reveal sites of activated microglia in both gray and white matter; however, the signal increases with the presence of activated astrocytes [48]. These investigations suggest that glial reaction may also be involved in the development of autism in concert with the microglial activation in the brain.

\section{Maternal Inflammatory Activation}

In addition to the strong evidence for the genetic transmission of autism, the maternal inflammatory response is one of the most contributing environmental risk factors in the etiology of autism [49]. Potential pathological effects have been investigated by using a wide variety of experimental models (table 1).

Polyriboinosinic-polyribocytidilic acid (poly I:C), a synthetic double-stranded RNA shown to bind to Tolllike receptor 3, leads to the activation of NF- $\mathrm{BB}$ (nuclear factor $\kappa$-light-chain-enhancer of activated $B$ cells) and the production of proinflammatory cytokines such as TNF- $\alpha$, IL-6 and IL-12 [50]. Poly I:C is often referred to as a viral mimetic as it activates the immune system and produces dose-dependent cytokine responses comparable to those occurring during naturally occurring or opportunistic viral infections [51]. In spiny mouse experiments, a single subcutaneous injection of a low dose of poly I:C at midgestation induces subclinical infections such as the common cold during pregnancies. However, the offspring showed significant impairments in nonspatial memory and learning tasks and demonstrated motor activity similar to autistic behaviors. A brain histological examination revealed a significantly decreased expression of reelin, an increased expression of glial fibrillary acidic protein and an increased number of activated microglia, specifically in the hippocampus [52]. These investigations imply that the prenatal subclinical infection and resultant activation of the maternal immune system could be risk factors for neurodevelopmental disorders such as autism. 
Pregnant mice with a BALB/c background exposed to influenza A virus (H3N2) on gestational day 9 bore autistic offspring (both male and female) with dose-dependent alterations in social and aggressive behaviors and increased locomotor behaviors, particularly in the males. This experiment also demonstrated changes in the catecholaminergic and microglial cell density in the brainstem tissues of male flu-exposed offspring only, suggesting an association between sex-specific alterations and dopamine metabolism and brainstem inflammation [53]. The $\mathrm{BALB} / \mathrm{c}$ mice used in this experiment are known to be more sensitive to the $\mathrm{H} 3 \mathrm{~N} 2$ virus than those with the $\mathrm{C} 57 \mathrm{Bl} / 6$ background. The BALB/c background has a greater Th1-type response than the $\mathrm{C} 57 \mathrm{Bl} / 6$ background, which has a greater Th2-type response [54]. The authors suggested that the genetic alterations in the maternal Th1 responses contribute to the developmental abnormalities in the offspring after gestational viral exposure [53].

Maternal inflammation during critical periods of embryonic development can cause brain overgrowth and autism-associated behaviors as a result of altered neural stem cell function [55]. ROS at nontoxic levels can increase stem cell self-renewal and neurogenesis through the reversible inactivation of the tumor suppressor gene PTEN protein and the subsequent enhancement of the PI3K pathway [56]. The maternal inflammatory response stimulates the generation of ROS through the actions of various cytokines and the activation of the NOX (NADPH oxidase) enzyme, which enhances signal transduction for many growth and trophic factors that are important for normal brain development [57]. Pregnant mice treated with low-dose LPS at embryonic day 9 had offspring with brain overgrowth, and a more pronounced effect was observed in the PTEN heterozygotes. The exposure to maternal inflammation also enhanced the NOX-PI3K pathway signaling, stimulated the hyperproliferation of neural stem and progenitor cells, increased the number of forebrain microglia, and produced abnormal autism-associated behaviors in affected pups. It has not yet been clarified whether the increase in microglia plays a role in stimulating progenitor proliferation [58] or in the phagocytic pruning of cells produced in excess following maternal inflammatory response exposure [17]. However, these murine models of maternal inflammation support the concept that prenatal neuroinflammatory dysregulation in neural stem cell redox signaling can act in concert with underlying genetic susceptibilities to affect the cellular responses to environmentally altered cellular levels of ROS [55].

Microglia in Autism

\section{Mast Cell-Microglia Interaction}

Microglia respond to proinflammatory signals released from nonneuronal cells, principally those of immune origin. Mast cells are of particular relevance in this context. They are derived from a distinct precursor in the bone marrow and mature under the influence of stem cell factor and various cytokines [59]. Mast cells also reside in the brain. It has been reported that rat brain mast cells, which were exclusively concentrated within the pia mater surrounding the diencephalon during embryonic stages, migrate along the penetrating vessels and enter the thalamus during development [60]. Nearly $97 \%$ of all brain mast cells lie on the abluminal side of the blood vessels. Mast cells are capable of migrating across the blood-brain barrier in situations where the barrier is compromised as a result of CNS pathology [61]. The high incidence of autism patients suffering from food or skin allergies [62] suggests the possibility that such mast cell-microglia interactions may contribute to the pathophysiology of neurodevelopmental disorders.

Among the inbred mouse strains that have been tested for abnormal behaviors, BTBR mice are among the most autistic-like strains. BTBR mice show low reciprocal social transference for food, high levels of repetitive selfgrooming, low levels of social approach and juvenile play, and an unusual pattern of ultrasonic vocalization; these traits are consistent with the core symptoms of autistic humans such as impaired communication, repetitive behavior and lowered reciprocal social interactions [63-66]. In evaluations of the immune system of BTBR mice, this strain showed the following: (1) significantly elevated levels of serum IgG and IgE, IgG anti-brain antibodies and IgG and IgE deposited in the brain, (2) an elevated expression of cytokines and (3) an increased proportion of MHC-II-expressing microglia compared to B6 mice. This study suggested that neuroinflammation may be due to the activated microglia or the increased presence of mast cells, which are prominent in circumventricular organs, the hippocampal fissure and the perivascular spaces in the posterior lateral thalamus. As a result, these areas may play a role in the occurrence of BTBR behavioral abnormalities [9].

\section{Microglial Dysfunction in Autism}

The possibility of deficits in the elimination of synapses during synaptic maturation (so-called 'pruning') has been investigated and may explain some of the behavioral and circuit-level deficits found in autism [67]. Mi- 
croglia play a critical role in pruning synapses during development [68]. Mice that have a transient reduction of microglia in the brain due to the failure to respond to the neuronally expressed chemokine fractalkine (fractalkine receptor knockout mice, $C \times 3 \mathrm{crl}^{\mathrm{KO}}$ ) show an excess amount of weak excitatory synapses due to the consequence of their failure to eliminate immature synaptic connections during the second and third postnatal weeks [69]. The $C x 3 c r 1^{\mathrm{KO}}$ mice also demonstrated that reduced synaptic pruning during development is associated with persistent deficits in synaptic multiplicity, reduced functional connectivity between the brain regions, impaired social interaction, and increased repetitive behavior phenotypes in autism. These results suggest the possibility that a primary deficit in the microglia may contribute to circuit-level deficits across neurodevelopmental disorders, including autism [67].

Mecp2-null microglia are reported to be toxic to neurons in vitro through the production of high levels of glutamate [70]. In a murine model of Rett syndrome, the transplantation of wild-type bone marrow into irradiation-conditioned Mecp2-null hosts resulted in the engraftment of brain parenchyma by bone marrow-derived myeloid cells of microglial phenotype and the arrest of disease development. These benefits mediated by wild-type microglia were diminished when the phagocytic activity was inhibited. These findings demonstrate that microglia play an important role in the pathophysiology of Rett syndrome [71], thereby suggesting the possibility of bone marrow transplantation as a potentially effective therapeutic approach for patients with autism.

\section{Conclusions and Future Perspectives}

Autism spectrum disorders are extremely heterogeneous. The rapidly growing list of genes and alleles that contribute to autism susceptibility suggests that many more genes will be discovered in the future. As we herein reviewed, microglia have a significant impact on several important etiological factors of autism such as the brain immune function, synaptic plasticity, brain circuitry, stem cell development, and the genetic interface for environmental stimuli. Further elucidation of the mechanisms and kinetics of microglial responses will therefore help to establish a window for therapeutic intervention in individuals with autism.

\section{Acknowledgment}

This work was supported by KAKENHI: Grant-in-Aid for Scientific Research (C; No. 15K09617).

\section{Disclosure Statement}

The author has no conflicts of interest to disclose.

\section{References}

1 Lai MC, Lombardo MV, Baron-Cohen S: Autism. Lancet 2014;383:896-910.

2 Ashwood P, Wills S, Van de Water J: The immune response in autism: a new frontier for autism research. J Leukoc Biol 2006;80:1-15.

-3 Noriega DB, Savelkoul HF: Immune dysregulation in autism spectrum disorder. Eur J Pediatr 2014;173:33-43.

4 Braunschweig D, Ashwood P, Krakowiak P, Hertz-Picciotto I, Hansen R, Croen LA, Pessah IN, Van de Water J: Autism: maternally derived antibodies specific for fetal brain proteins. Neurotoxicology 2008;29:226-231.

-5 Singer HS, Morris CM, Gause CD, Gillin PK, Crawford S, Zimmerman AW: Antibodies against fetal brain in sera of mothers with autistic children. J Neuroimmunol 2008;194: 165-172.

6 Croen LA, Braunschweig D, Haapanen L, Yoshida CK, Fireman B, Grether JK, Kharrazi M, Hansen RL, Ashwood P, Van de Water J: Maternal mid-pregnancy autoantibodies to fetal brain protein: the early markers for autism study. Biol Psychiatry 2008;64:583-588.

7 Martin LA, Ashwood P, Braunschweig D, Cabanlit M, Van de Water J, Amaral DG: Stereotypies and hyperactivity in rhesus monkeys exposed to IgG from mothers of children with autism. Brain Behav Immun 2008;22:806-816.

8 Singer HS, Morris C, Gause C, Pollard M, Zimmerman AW, Pletnikov M: Prenatal exposure to antibodies from mothers of children with autism produces neurobehavioral alterations: a pregnant dam mouse model. J Neuroimmunol 2009;211:39-48.

-9 Heo Y, Zhang Y, Gao D, Miller VM, Lawrence DA: Aberrant immune responses in a mouse with behavioral disorders. PLoS One 2011; 6:e20912.

10 Martínez-Cerdeño V, Camacho J, Fox E, Miller E, Ariza J, Kienzle D, Plank K, Noctor SC, Van de Water J: Prenatal exposure to autismspecific maternal autoantibodies alters proliferation of cortical neural precursor cells, en- larges brain, and increases neuronal size in adult animals. Cereb Cortex 2014, Epub ahead of print.

11 Courchesne E, Pierce K: Why the frontal cortex in autism might be talking only to itself: local over-connectivity but long-distance disconnection. Curr Opin Neurobiol 2005; 15 : 225-230.

12 Perry VH, Nicoll JA, Holmes C: Microglia in neurodegenerative disease. Nat Rev Neurol 2010;6:193-201.

13 Ajami B, Bennett JL, Krieger C, Tetzlaff W, Rossi FM: Local self-renewal can sustain CNS microglia maintenance and function throughout adult life. Nat Neurosci 2007;10:15381543.

14 Ginhoux F, Greter M, Leboeuf M, Nandi S, See P, Gokhan S, Mehler MF, Conway SJ, Ng LG, Stanley ER, Samokhvalov IM, Merad M: Fate mapping analysis reveals that adult microglia derive from primitive macrophages. Science 2010;330:841-845. 
15 Czeh M, Gressens P, Kaindl AM: The yin and yang of microglia. Dev Neurosci 2011;33: 199-209.

16 Boche D, Perry VH, Nicoll JA: Review: activation patterns of microglia and their identification in the human brain. Neuropathol Appl Neurobiol 2013;39:3-18.

-17 Cunningham CL, Martínez-Cerdeño V, Noctor SC: Microglia regulate the number of neural precursor cells in the developing cerebral cortex. J Neurosci 2013;33:4216-4233.

-18 Shigemoto-Mogami Y, Hoshikawa K, Goldman JE, Sekino Y, Sato K: Microglia enhance neurogenesis and oligodendrogenesis in the early postnatal subventricular zone. J Neurosci 2014;34:2231-2243.

19 Hanisch UK, Kettenmann H: Microglia: active sensor and versatile effector cells in the normal and pathologic brain. Nat Neurosci 2007;10:1387-1394.

20 Varnum MM, Ikezu T: The classification of microglial activation phenotypes on neurodegeneration and regeneration in Alzheimer's disease brain. Arch Immunol Ther Exp (Warsz) 2012;60:251-266.

21 Chao CC, Hu S, Molitor TW, Shaskan EG, Peterson PK: Activated microglia mediate neuronal cell injury via a nitric oxide mechanism. J Immunol 1992;149:2736-2741.

22 Bhat NR, Zhang P, Lee JC, Hogan EL: Extracellular signal-regulated kinase and p38 subgroups of mitogen-activated protein kinases regulate inducible nitric oxide synthase and tumor necrosis factor-alpha gene expression in endotoxin-stimulated primary glial cultures. J Neurosci 1998;18:1633-1641.

23 Takeuchi H, Jin S, Wang J, Zhang G, Kawanokuchi J, Kuno R, Sonobe Y, Mizuno T, Suzumura A: Tumor necrosis factor-alpha induces neurotoxicity via glutamate release from hemichannels of activated microglia in an autocrine manner. J Biol Chem 2006;28: 21362-21368.

24 Meda L, Cassatella MA, Szendrei GI, Otvos L Jr, Baron P, Villalba M, Ferrari D, Rossi F: Activation of microglial cells by beta-amyloid protein and interferon-gamma. Nature 1995; 374:647-650.

25 Pais TF, Figueiredo C, Peixoto R, Braz MH, Chatterjee S: Necrotic neurons enhance microglial neurotoxicity through induction of glutaminase by a MyD88-dependent pathway. J Neuroinflammation 2008;5:43.

26 Maezawa I, Zimin PI, Wulff H, Jin LW: Amyloid-beta protein oligomer at low nanomolar concentrations activates microglia and induces microglial neurotoxicity. J Biol Chem 2011; 286:3693-3706.

27 Codolo G, Plotegher N, Pozzobon T, Brucale M, Tessari I, Bubacco L, de Bernard M: Triggering of inflammasome by aggregated a-synuclein, an inflammatory response in synucleinopathies. PLoS One 2013;8:e55375.

28 Zhang W, Wang T, Pei Z, Miller DS, Wu X, Block ML, Wilson B, Zhang W, Zhou Y, Hong JS, Zhang J: Aggregated alpha-synuclein activates microglia: a process leading to disease progression in Parkinson's disease. FASEB J 2005; 19:533-542.

29 Fernandes A, Miller-Fleming L, Pais TF: Microglia and inflammation: conspiracy, controversy or control? Cell Mol Life Sci 2014;71: 3969-3985.

30 Freilich RW, Woodbury ME, Ikezu T: Integrated expression profiles of mRNA and miRNA in polarized primary murine microglia. PLoS One 2013;8:e79416.

-31 Zhao W, Xie W, Xiao Q, Beers DR, Appel SH: Protective effects of an anti-inflammatory cytokine, interleukin- 4 , on motoneuron toxicity induced by activated microglia. J Neurochem 2006;99:1176-1187.

-32 Shimizu E, Kawahara K, Kajizono M, Sawada M, Nakayama H: IL-4-induced selective clearance of oligomeric beta-amyloid peptide $_{1-42}$ by rat primary type 2 microglia. J Immunol 2008; 181:6503-6513.

33 Miron VE, Boyd A, Zhao JW, Yuen TJ, Ruckh JM, Shadrach JL, van Wijngaarden P, Wagers AJ, Williams A, Franklin RJ, ffrench-Constant C: M2 microglia and macrophages drive oligodendrocyte differentiation during CNS remyelination. Nat Neurosci 2013;16:12111218.

34 Stoner R, Chow ML, Boyle MP, Sunkin SM, Mouton PR, Roy S, Wynshaw-Boris A, Colamarino SA, Lein ES, Courchesne E: Patches of disorganization in the neocortex of children with autism. N Engl J Med 2014;370:12091219.

35 Schumann CM, Noctor SC, Amaral DG: Neuropathology of autism spectrum disorders: postmortem studies; in Amaral DG, Dawson G, Geschwind DH (eds): Autism Spectrum Disorders. New York, Oxford University Press, 2011, pp 539-565.

36 Casanova MF, van Kooten IA, Switala AE, van Engeland H, Heinsen H, Steinbusch HW, Hof PR, Trippe J, Stone J, Schmitz C: Minicolumnar abnormalities in autism. Acta Neuropathol 2006;112:287-303.

37 Vargas DL, Nascimbene C, Krishnan C, Zimmerman AW, Pardo CA: Neuroglial activation and neuroinflammation in the brain of patients with autism. Ann Neurol 2005;57: 67-81.

38 Tetreault NA, Hakeem AY, Jiang S, Williams BA, Allman E, Wold BJ, Allman JM: Microglia in the cerebral cortex in autism. J Autism Dev Disord 2012;42:2569-2584.

39 Morgan JT, Chana G, Abramson I, Semendeferi K, Courchesne E, Everall IP: Abnormal microglial-neuronal spatial organization in the dorsolateral prefrontal cortex in autism. Brain Res 2012;1456:72-81.

40 Schumann CM, Hamstra J, Goodlin-Jones BL, Lotspeich LJ, Kwon H, Buonocore MH, Lammers CR, Reiss AL, Amaral DG: The amygdala is enlarged in children but not adolescents with autism; the hippocampus is enlarged at all ages. J Neurosci 2004;24:63926401.

41 Morgan JT, Barger N, Amaral DG, Schumann CM: Stereological study of amygdala glial populations in adolescents and adults with autism spectrum disorder. PLoS One 2014; 9:e110356.

42 Gupta S, Ellis SE, Ashar FN, Moes A, Bader JS, Zhan J, West AB, Arking DE: Transcriptome analysis reveals dysregulation of innate immune response genes and neuronal activitydependent genes in autism. Nat Commun 2014;5:5748.

- 43 Papadopoulos V, Baraldi M, Guilarte TR Knudsen TB, Lacapère JJ, Lindemann P, Norenberg $\mathrm{MD}$, Nutt $\mathrm{D}$, Weizman $\mathrm{A}$, Zhang $\mathrm{MR}$, Gavish M: Translocator protein $(18 \mathrm{kDa})$ : new nomenclature for the peripheral-type benzodiazepine receptor based on its structure and molecular function. Trends Pharmacol Sci 2006;27:402-409.

44 Banati RB: Visualising microglial activation in vivo. Glia 2002;40:206-217.

-45 Suzuki K, Sugihara G, Ouchi Y, Nakamura K, Futatsubashi M, Takebayashi K, Yoshihara Y, Omata K, Matsumoto K, Tsuchiya KJ, Iwata Y, Tsujii M, Sugiyama T, Mori N: Microglial activation in young adults with autism spectrum disorder. JAMA Psychiatry 2013;70:4958.

46 Venneti S, Lopresti BJ, Wiley CA: The peripheral benzodiazepine receptor (translocator protein $18 \mathrm{kDa}$ ) in microglia: from pathology to imaging. Prog Neurobiol 2006;80: 308-322.

47 Lavisse S, Guillermier M, Hérard AS, Petit F, Delahaye M, Van Camp N, Ben Haim L, Lebon V, Remy P, Dollé F, Delzescaux T, Bonvento G, Hantraye P, Escartin C: Reactive astrocytes overexpress TSPO and are detected by TSPO positron emission tomography imaging. J Neurosci 2012;32:1080910818.

48 Dickens AM, Vainio S, Marjamäki P, Johansson J, Lehtiniemi P, Rokka J, Rinne J, Solin O, Haaparanta-Solin M, Jones PA, Trigg W, Anthony DC, Airas L: Detection of microglial activation in an acute model of neuroinflammation using PET and radiotracers ${ }^{11} \mathrm{C}-(\mathrm{R})$ PK11195 and 18F-GE-180. J Nucl Med 2014; 55:466-472.

49 Patterson PH: Maternal infection and immune involvement in autism. Trends $\mathrm{Mol}$ Med 2011;17:389-394.

50 Alexopoulou L, Holt AC, Medzhitov R, Flavell RA: Recognition of double-stranded RNA and activation of NF- $\kappa B$ by Toll-like receptor 3. Nature 2001;413:732-738.

51 Cunningham C, Campion S, Teeling J, Felton L, Perry VH: The sickness behaviour and CNS inflammatory mediator profile induced by systemic challenge of mice with synthetic double-stranded RNA (poly I:C). Brain Behav Immun 2007;21:490-502.

52 Ratnayake U, Quinn TA, Castillo-Melendez M, Dickinson H, Walker DW: Behaviour and hippocampus-specific changes in spiny mouse neonates after treatment of the mother with the viral-mimetic poly I:C at mid-pregnancy. Brain Behav Immun 2012;26:12881299. 
53 Miller VM, Zhu Y, Bucher C, McGinnis W, Ryan LK, Siegel A, Zalcman S: Gestational flu exposure induces changes in neurochemicals, affiliative hormones and brainstem inflammation, in addition to autism-like behaviors in mice. Brain Behav Immun 2013;33:153163.

54 Watanabe $\mathrm{H}$, Numata K, Ito T, Takagi K, Matsukawa A: Innate immune response in Th1- and Th2-dominant mouse strains. Shock 2004;22:460-466.

55 Le Belle JE, Sperry J, Ngo A, Ghochani Y, Laks DR, López-Aranda M, Silva AJ, Kornblum HI: Maternal inflammation contributes to brain overgrowth and autism-associated behaviors through altered redox signaling in stem and progenitor cells. Stem Cell Reports 2014;3:725-734.

56 Le Belle JE, Orozco NM, Paucar AA, Saxe JP, Mottahedeh J, Pyle AD, Wu H, Kornblum HI: Proliferative neural stem cells have high endogenous ROS levels that regulate self-renewal and neurogenesis in a PI3K/Akt-dependent manner. Cell Stem Cell 2011;8:59-71.

57 Beloosesky R, Weiner Z, Ginsberg Y, Ross MG: Maternal N-acetyl-cysteine (NAC) protects the rat fetal brain from inflammatory cytokine responses to lipopolysaccharide (LPS). J Matern Fetal Neonatal Med 2012;25:13241328.
58 Antony JM, Paquin A, Nutt SL, Kaplan DR, Miller FD: Endogenous microglia regulate development of embryonic cortical precursor cells. J Neurosci Res 2011;89:286-298.

59 Galli SJ, Nakae S, Tsai M: Mast cells in the development of adaptive immune responses. Nat Immunol 2005;6:135-142.

60 Lambracht-Hall M, Dimitriadou V, Theoharides TC: Migration of mast cells in the developing rat brain. Brain Res Dev Brain Res 1990; 56:151-159.

61 Skaper SD, Giusti P, Facci L: Microglia and mast cells: two tracks on the road to neuroinflammation. FASEB J 2012;26:3103-3117.

62 Theoharides TC, Asadi S, Patel AB: Focal brain inflammation and autism. J Neuroinflammation 2013; 10:46.

63 Moy SS, Nadler JJ, Young NB, Perez A, Holloway LP, Barbaro RP, Barbaro JR, Wilson LM, Threadgill DW, Lauder JM, Magnuson TR, Crawley JN: Mouse behavioral tasks relevant to autism: phenotypes of 10 inbred strain. Behav Brain Res 2007;176:4-20.

64 Bolivar VJ1, Walters SR, Phoenix JL: Assessing autism-like behavior in mice: variations in social interactions among inbred strains. Behav Brain Res 2007;176:21-26.
65 McFarlane HG, Kusek GK, Yang M, Phoenix JL, Bolivar VJ, Crawley JN: Autism-like behavioral phenotypes in BTBR $\mathrm{T}+\mathrm{tf} / \mathrm{J}$ mice. Genes Brain Behav 2008;7:152-163.

66 Wöhr M, Roullet FI, Crawley JN: Reduced scent marking and ultrasonic vocalizations in the BTBR $\mathrm{T}+\mathrm{tf} / \mathrm{J}$ mouse model of autism. Genes Brain Behav 2011;10:35-43.

67 Zhan Y, Paolicelli RC, Sforazzini F, Weinhard L, Bolasco G, Pagani F, Vyssotski AL, Bifone A, Gozzi A, Ragozzino D, Gross CT: Deficient neuron-microglia signaling results in impaired functional brain connectivity and social behavior. Nat Neurosci 2014;17:400-406.

68 Paolicelli RC, Gross CT: Microglia in development: linking brain wiring to brain environment. Neuron Glia Biol 2011;7:77-83.

69 Paolicelli RC, Bolasco G, Pagani F, Maggi L, Scianni M, Panzanelli P, Giustetto M, Ferreira TA, Guiducci E, Dumas L, Ragozzino D, Gross CT: Synaptic pruning by microglia is necessary for normal brain development. Science 2011;333:1456-1458

70 Maezawa I, Jin LW: Rett syndrome microglia damage dendrites and synapses by the elevated release of glutamate. J Neurosci 2010;30: 5346-5356.

-71 Derecki NC, Cronk JC, Lu Z, Xu E, Abbott SB, Guyenet PG, Kipnis J: Wild-type microglia arrest pathology in a mouse model of Rett syndrome. Nature 2012;484:105-109. 